Prophetic: Professional, Empathy and Islamic Counseling Journal

Vol. 4, No. 1, Juni 2021, hlm. 59-70

e-ISSN : 2685-0702, p-ISSN : 2654-3958

Tersedia Online di http://syekhnurjati.ac.id/jurnal/index.php/prophetic

Email: prophetic@syekhnurjati.ac.id

\title{
Strategi Meningkatkan Kontrol Diri di Masa Pandemi COVID-19
}

\author{
Rina Kurnia \\ Program Studi Bimbingan Konseling Islam, Fakultas Ushuluddin Adab dan Dakwah, \\ IAIN Syekh Nurjati Cirebon \\ rina_kurnia@syekhnurjati.ac.id
}

\begin{abstract}
Abstrak
Pandemi COVID-19 yang tengah mewadah seluruh dunia termasuk Indonesia memberikan dampak yang negatif bagi seluruh aspek kehidupan. Pandemi COVID-19 berhasil mengubah kebiasaan sehari-hari baik di rumah, di sekolah, di tempat kerja, di jalan, di tempat ibadah, dan dimanapun. Kebiasaan baru untuk hidup bersih dan sehat mesti dilakukan oleh masyarakat sehingga menjadi norma individu dan norma sosial baru dalam kehidupan sehari-hari. Perubahan sikap dan perilaku masyarakat pada masa kenormalan baru di tengah pandemi COVID-19 membutuhkan perjuangan dalam bentuk penyesuaian diri dan kontrol diri yang tinggi untuk memutus penyebaran virus agar kehidupan kembali tertata dengan baik. Tujuan penelitian ini adalah memberikan pandangan mengenai strategi meningkatkan kontrol diri di masa pandemi COVID-19. Adapun metode penelitian yang digunakan yaitu metode kualitatif dengan pendekatan kepustakaan. Sumber data didapatkan dari artikel, jurnal, buku, dokumen resmi, penelitian terdahulu, dan media sosial. Hasil penelitian ini diketahui melalui strategistrategi yang dapat dilakukan untuk meningkatkan kontrol diri individu atau masyarakat di tengah pandemi diharapkan dapat memutus mata rantai penyebaran COVID-19.
\end{abstract}

Kata Kunci: Pandemi Covid-19; Kontrol Diri; Kenormalan Baru.

\section{PENDAHULUAN}

Akhir tahun 2019, pertama kali muncul Corona Virus Disease (COVID-19) di Wuhan China dan menyebar secara cepat ke seluruh dunia sehingga pada tanggal 11 Maret 2020 WHO mengumumkan serangan COVID-19 sebagai pandemi global. Tercatat 213 negara telah terkonfirmasi terinfeksi COVID-19 dengan total kasus 164 juta (news.google.com). Di Indonesia, seluruh provinsi telah terdeteksi kasus COVID-19. Per tanggal 18 Mei 2021 terdapat penambahan 4.185 kasus baru, rata-rata per 7 hari terakhir sebanyak 3.519 kasus, sehingga menurut Our World in Data dan JHU CSSE COVID-19 data total kasus di Indonesia sampai tanggal 18 Mei 2021 tercatat sebanyak 1,75 juta, sembuh 1,61 juta, dan meninggal 48.477 jiwa. DKI Jakarta sebagai ibu kota negara Indonesia menduduki peringkat pertama dalam penyebaran COVID-19 sebanyak 419.848 
(24,0\%) kasus. Disusul oleh Jawa Barat sebanyak 299.784 (17,1\%) kasus, Jawa Tengah sebanyak $191.184(10,9 \%)$ kasus, Jawa Timur sebanyak $151.677(8,7 \%)$ kasus dan peringkat ke 34 (terakhir) diduduki oleh Provinsi Maluku Utara dengan jumlah kasus 4.453 $(0,3 \%)$ (covid19.go.id/peta-sebaran).

Virus SARS-Cov-2 atau dikenal dengan nama virus Corona/COVID-19 merupakan virus yang termasuk dalam kelompok virus penyebab Severe Acute Respiratory Syndrome (SARS) dan Middle-East Respiratory Syndrome (MERS). Meski disebabkan oleh virus dari kelompok yang sama, COVID-19 memiliki perbedaan dengan SARS dan MERS terutama pada kecepatan dan keparahan gejala. Dalam hitungan bulan saja, virus ini sudah menyebar ke seluruh negara di dunia. Virus COVID-19 dapat meneyerang kepada siapa saja, seperti lansia, orang dewasa, anak-anak dan bayi, termasuk ibu hamil dan ibu menyusui. Virus yang menyebabkan COVID-19 ditularkan melalui droplet (percikan air liur) yang dihasilkan saat orang yang terinfeksi batuk, bersin, atau hembusan nafas. Droplet tersebut terlalu berat dan tidak bisa bertahan di udara, sehingga dengan cepat jatuh dan menempel pada lantai atau permukaan lainnya. Penularan dapat terjadi pada saat menghirup udara yang mengandung virus jika berada terlalu dekat dengan orang yang terinfeksi COVID-19 dan dapat pula tertular jika menyentuh permukaan benda yang terkontaminasi lalu menyentuh mata, hidung, atau mulut.

Adapun gejala awal infeksi virus COVID-19 menyerupai gejala flu, yaitu demam, pilek, batuk kering, sakit tenggorokan, dan sakit kepala. Setelah itu, gejala dapat hilang dan sembuh atau semakin memberat. Penderita dengan gejala yang berat dapat mengalami demam tinggi, batuk berdahak bahkan berdarah, sesak napas, dan nyeri dada. Gejala lainnya, diare, hilangnya kemampuan mengecap rasa, mencium bau dan ruam di kulit. Gejala-gejala tersebut umumnya muncul dalam waktu 2 hari sampai 2 minggu setelah penderita terpapar virus COVID-19. Guna memastikan gejala-gejala tersebut mengarah ke COVID-19 atau bukan diperlukan rapid test atau PCR (Polymerase Chain Reaction). Jika terpapar COVID-19 tetapi tidak menunjukkan gejala serius cukup lakukan isolasi mandiri di rumah selama 14 hari dengan arahan dokter. Namun, jika gejala terasakan berat segera datang ke rumah sakit yang ditunjuk untuk dilakukan perawatan lebih intensif.

Berbagai kebijakan preventif telah digaungkan oleh pemerintah sebagai upaya meringankan dampak dan menekan peyebaran COVID-19. Diantaranya, Pemerintah menerbitkan Peraturan Pemerintah Pengganti Undang-Undang (Perpu) Nomor 1 Tahun 2020 tentang Kebijakan Keuangan Negara dan Stabilitas Sistem Keuangan untuk Penanganan Pandemi COVID-19 dan/atau dalam Rangka Menghadapi Ancaman yang Membahayakan Perekonomian Nasional yaitu (1) tambahan belanja APBN 2020 senilai 405,1 triliun; (2) prioritas anggaran di bidang kesehatan; (3) prioritas anggaran untuk perlindungan sosial; (4) prioritas anggaran untuk dunia usaha; (5) prioritas di bidang non fiscal; (6) revisi batas maksimal defisit APBN; dan (7) kebijakan moneter. Dengan diterbitkannya peraturan tersebut, diharapkan dapat memberikan berbagai kemudahan dan keringanan bagi masyarakat yang terdampak pandemi COVID-19. 
Adapun upaya lainnya dalam rangka memutus penyebaran COVID-19 dengan membatasi ruang gerak masyarakat, pemerintah menebitkan peraturan Pemerintah Nomor 21 tahun 2020 tentang Pembatasan Sosial Berskala Besar (PSBB) dan diturunkan oleh Kementerian Kesehatan melalui Peraturan Menteri Kesehatan Nomor 9 Tahun 2020 tentang Pedoman Pembatasan sosial Berskala Besar dalam Rangka Percepatan Penanganan COVID-19 yang bertujuan untuk menekan angka kenaikan kasus COVID-19. Begitu pula dengan kebijakan dilarang mudik tahun 2021 ini, masyarakat dihimbau untuk tidak merayakan idul fitri di kampung halaman.

Selain itu, untuk meningkatkan daya tahan tubuh masyarakat sebagai bentuk perlindungan diri terhadap penyakit, pemerintah mengadakan program vaksinasi. Vaksinasi adalah proses pemberian vaksin ke dalam tubuh. Kandungan vaksin dapat berupa bakteri atau virus yang telah dilemahkan atau dimatikan, bisa juga berupa bagian dari bakteri atau virus tersebut. Pemberian vaksin COVID-19 oleh pemerintah akan dilakukan secara bertahap mengingat pasokan vaksin yang belum mencukupi jika dilakukan secara bersamaan. Pemberian vaksin COVID-19 ditujukan untuk penurunan angka kasus positif dan kematian COVID-19, serta terbentuknya herd immunity. Dengan demikian, dampak ekonomi dan sosial akibat wabah ini dapat diminimalkan (alodokter.com). Meski telah divaksin, tetaplah mematuhi protokol kesehatan untuk mencegah penularan COVID-19.

Akan tetapi pada kenyataannya, meskipun telah beberapa kali diterapkan PSBB diberbagai daerah angka kenaikan kasus COVID-19 semakin meroket. Berbagai himbauan dan larangan hanya sebagai ucapan dari pemerintah tanpa dihiraukan oleh masyarakat. Semakin meroketnya kasus terkonfirmasi COVID-19 menjadikan Indonesia berada pada situasi yang memprihatinkan. Daya tampung rumah sakit pun hampir melebihi batas maksimal. Hal ini menandakan berbagai regulasi mengenai PSBB yang bertujuan menekan penyebaran kasus COVID-19 belum dikatakan berhasil. Semakin lama pelaksanaan PSBB di berbagai kota di Indonesia, semakin lama pula keterbatasan aktivitas masyarakat. Hal ini berdampak terhadap seluruh aspek kehidupan, diantaranya penurunan dan pelambatan ekonomi (resesi), terganggu aktivitas pendidikan, ekonomi dan sosial, dan yang paling mengkhawatirkan dampak psikologis dan perubahan perilaku masyarakat (Agung, 2020).

Pandemi COVID-19 yang masih melanda tetapi kehidupan harus berjalan, roda ekonomi mesti digerakkan, di saat yang sama perlu kewaspadaan agar penyebaran virus dapat ditekan. Menghadapi tantangan-tantangan baru tersebut diperlukan kontrol diri dalam adaptasi kebiasaan baru untuk menjalankan kehidupan sehari-hari. Berbagai tindakan pencegahan melalui protokol kesehatan seperti menggunakan masker secara benar, selalu menjaga jarak dengan siapapun di luar rumah dan hindari kerumunan, serta mencuci tangan pakai sabun dengan air mengalir selama minimal 20 detik. Jika setiap orang memiliki kontrol diri yang baik dan mampu bekerjasama untuk melindungi diri dan orang lain, maka pandemi COVID-19 ini akan cepat berakhir.

Setiap individu memiliki sistem pengaturan diri yang memusatkan perhatian pada pengontrolan diri. Kontrol diri merupakan salah satu faktor internal yang mempengaruhi kecenderungan individu untuk mengatur dan memperhatikan cara-cara yang tepat untuk 
berperilaku dalam situasi yang bervariasi, mengendalikan emosi dan dorongan dari dalam dirinya (Hurlock, 1990). Menurut Tangney, Baumister, Boone (Istiqlal, 2019) terdapat tiga aspek dalam kemampuan mengontrol diri yaitu melanggar kebiasaan, menahan godaan, dan disiplin diri. Melanggar kebiasaan dimaksudkan melakukan sesuatu di luar kebiasaan. Menahan godaan berkaitan dengan proses kognitif yang memberikan penilaian terhadap pengaturan diri yang dimanifestasikan dalam bentuk perilaku. Disiplin diri mengacu pada kemampuan untuk mengontrol diri dari hal-hal yang mengganggu konsentrasinya. Kontrol diri membantu individu untuk dapat memandu, mengarahkan dan mengatur dirinya dengan kuat pada sesuatu yang positif (Lazarus, 1976). Oleh karena itu, di masa pandemi COVID19, kontrol diri yang dimanifestasikan dalam bentuk menjalankan protokol kesehatan yang ketat diperlukan oleh masyarakat untuk menekan penularan virus.

\section{METODE PENELITIAN}

Metode penelitian yang digunakan dalam penelitian ini yaitu metode kualitatif dengan pendekatan deskriptif. Sugiyono (2018) mengartikan penelitian kualitatif sebagai proses eksplorasi dan pemahaman makna dari perilaku individu dan kelompok, serta menggambarkan masalah sosial atau masalah kemanusiaan yang berada di sekitar. Pendekatan deskripsi digunakan untuk memahami makna dan keunikan obyek yang diteliti serta memahami interaksi sosial yang berada di masyarakat. Penelitian ini dimulai dari pengumpulan data berupa artikel, jurnal, penelitian terdahulu, dan buku yang membahas mengenai pandemi COVID-19 dan strategi kontrol diri. Sumber lainnya seperti media sosial digunakan untuk memperkuat data kasus yang terjadi dan menjaga kredibilitas data tersebut.

\section{HASIL DAN PEMBAHASAN}

\section{Pandemi COVID-19 Berdasarkan Perspektif Kognitif dan Psikologi}

Berdasarkan tingkat kecepatan dan keluasan penyebaran di beberapa negara dan mempengaruhi hidup orang banyak, WHO menetapkan COVID-19 sebagai pandemi global. Istilah pandemi didefinisikan sebagai penyakit menular yang berjangkit dengan cepat menyebar ke seluruh dunia atau di wilayah yang sangat luas, melintasi batas internasional dan memengaruhi sejumlah besar orang (Kelly, 2011). Karakteristik pandemi yang disertai kemajuan teknologi informasi (internet, media sosial), penyebaran COVID-19 secara luas dan cepat berdampak terhadap psikologis secara signifikan. Perubahan cara berpikir individu dalam memahami informasi tentang sehat dan sakit, perubahan emosi seperti takut, khawatir dan cemas yang berlebihan, serta perilaku sosial seperti menghindar, stigmatisasi dan perilaku sehat merupakan dampak pandemi COVID-19 yang secara terang-terangan ditunjukkan oleh individu sekarang ini.

Secara kognitif, respon individu dalam menghadapi situasi pandemi COViD-19 sangat beragam. Diawali dari penerimaan informasi mengenai COVID-19 baik yang positif atau negatif kemudian diproses atau dikelola dalam otak, sehingga menghasilkan suatu respon kognitif berupa penilaian atas informasi tersebut. Penilaian tersebut akan digunakan 
untuk memahami dunia sosial atau disebut kognisi sosial (Taylor dalam Agung, 2020). Namun jika gagal, maka akan muncul bias-bias dalam kognisi sosial, overconfidence, bias optimis seperti heuristik yang akan mempengaruhi individu dalam berpikir dan berperilaku (Agung, 2020).

Berdasarkan hal penelitian yang dilakukan oleh Iskandarsyah \& Yudiana (2020) terhadap 3686 partisipan dari berbagai wilayah Indonesia menunjukkan 44,9\% sebanyak < 3 kali, 37\% sebanyak 4-5 kali, 9,9\% 6-10 kali, dan 8,2\% > 10 kali mengakses informasi mengenai pandemi COVID-19. Hasil penelitian tersebut menunjukkan keterbukaan informasi mengenai COVID-19 baik positif maupun negatif, yang mudah diakses dari berbagai media menimbulkan potensi bias kognitif yang semakin besar. Informasi COVID19 yang positif cenderung menjadikan masyarakat lebih waspada dan khawatir. Akan tetapi, informasi yang bernada negatif seperti jumlah orang terinfeksi dan kematian tidak cukup membuat sebagian besar patuh melindungi dirinya dengan menggunakan masker, menjaga jarak, dan menghindari kerumunan sehingga berdampak pada meningkatnya jumlah yang terinfeksi tanpa gejala. Hal tersebut terjadi karena bias kognisi seperti overconfidence (cenderung terlalu percaya diri) dan bias optimistik.

Secara psikologis yang dimanifestasikan dalam bentuk respon emosi, penyebaran Covid-19 mempengaruhi masyarakat dari berbagai kalangan. Dengan adanya pandemi Covid-19 menimbulkan situasi yang penuh ancaman, ketidakpastian, keterbatasan relasi sosial membuat sebagian besar masyarakat merasa cemas dan dalam kondisi tertekan (Iskandarsyah dan Yudiana, 2020), penurunan emosi positif (kebahagiaan, kepuasaan hidup) dan peningkatan emosi negatif seperti cemas dan stress (Li, dkk, 2020).

Menurut Agus (2020), sebenarnya perubahan emosi seperti khawatir, cemas, dan stress merupakan respon biasa sebagai bentuk mekanisme pertahanan diri terhadap ancaman yang harus dihadapi. Namun, jika berlebihan, maka akan mengganggu kondisi psikologis individu. Selanjutnya, Agus (2020) mengatakah bahwa secara umum kondisi psikologis pada masa pandemi masih dalam tataran normal, yang perlu dikhawatirkan yaitu dampak pandemi Covid-19 terhadap ekomoni. Mengapa demikian? Berdasarkan data Kementerian Ketenagakerjaan tercatat sampai tanggal 20 April 2020 sebanyak 2.084.593 pekerja dari sektor formal dan informal yang berasal dari 116.370 perusahaan terkena dampak Covid-19 (Kemnaker.go.id). Hal ini berpengaruh terhadap pemenuhan kebutuhan hidup. Jika pemenuhan kebutuhan hidup terganggu maka rentan menimbulkan gangguan psikologis, artinya pandemi Covid-19 secara tidak langsung mempengaruhi kondisi psikologis.

Penyebaran Covid-19 secara cepat hanya dalam hitungan bulan, telah mengubah perilaku sosial sebagai respon adaptasi terhadap pandemi. Perubahan sosial terjadi pada seluruh sektor kehidupan, seperti pendidikan, ekonomi, politik, agama, dan sebagainya. Berbagai himbauan yang digaungkan pemerintah seperti pembatasan skala besar, belajar, bekerja, dan beribadah dari rumah, cuci tangan pakai sabun di air yang mengalir, jaga jarak, menghindari kerumunan, dan menggunakan masker sebagai upaya untuk menekan penyebaran Covid-19. Meski segala upaya telah dilakukan, pandemi ini terus mengancam 
keselamatan diri. Secara grafik, kasus per hari semakin meningkat. Oleh karena itu, perlu berbagai upaya yang dapat dilakukan untuk menangani penyebaran Covid-19 ini yaitu penyesuaian dan kontrol diri, kepatuhan dan solidaritas dari semua pihak untuk menerapkan adaptasi kebiasaan baru dalam aktivitas sehari-hari.

\section{Kenormalan Baru}

Berbagai upaya telah pemerintah lakukan untuk mengurangi penyebaran COVID-19, termasuk kebijakan PSBB yang membatasi aktivitas masyarakat. Namun kebijakan ini tidak bisa dilakukan terus menerus. Masyarakat harus tetap bekerja untuk memenuhi kebutuhan, pendidikan harus tetap berjalan dan perekonomian harus tetap berputar. Meski pemerintah menggelontorkan berbagai bantuan sosial bagi masyarakat yang terdampak, tetapi tidak bisa dilakukan terus menerus.

Pandemi COVID-19 yang melanda dunia mengakibatkan perubahan di seluruh aspek kehidupan sehingga perlu penyesuaian situasi dari sebelumnya yang dinamakan dengan kenormalan baru. Kenormalan baru atau dalam istilah Bahasa Inggris disebut new normal merupakan suatu upaya mempersiapkan masyarakat untuk beradaptasi dan menjalankan perubahan perilaku yang baru agar leluasa beraktivitas di luar rumah ditengah pandemi COVID-19 yang belum usai (Nuramdani, 2020). New normal adalah istilah yang digunakan ketika memasuki kondisi baru, kebiasaan baru setelah lepas/tidak bisa lepas dari suatu wabah atau kondisi, sehingga masyarakat perlu penyesuaian diri dengan kebiasaan baru, perilaku baru dalam membatasi diri untuk mencegah terinfeksinya virus (Rohmah, 2021). Kenormalan baru sebagai upaya mengembalikan kehidupan masyarakat secara normal dengan penyesuaian dan kebiasaan baru terutama untuk hidup bersih dan sehat. Kenormalan baru menuntut masyarakat untuk hidup berdampingan dengan COVID-19 dengan melaksanakan protokol kesehatan sebagai bentuk pencegahan penyebaran dan penularan COVID-19.

Adapun panduan yang harus diperhatikan oleh masyarakat dalam menjalani kenormalan baru menurut Nuramdani (2020) sebagai berikut.

1. Pencegahan virus pada transportasi umum

Bagi yang akan bepergian jarak dekat diharapkan tetap melaksanakan protokol kesehatan seperti memakai masker, menjaga jarak tempat duduk, membawa hand sanitizer dan menggunakan sarung tangan jika diperlukan, tidak memegang gagang pintu atau pegangan yang ada di dalam kendaraan. Bagi yang akan bepergian jarak jauh menggunakan transportasi kereta api, pesawat, atau kapal laut diwajibkan untuk memiliki hasil tes swab yang menyatakan negatif dari COVID-19. Kapasitas transportasi umum pun dibatasi maksimal 50\% dari semestinya.

2. Mencegah virus selama beraktivitas di tempat kerja

Di masa PSBB atau PPKM pemerintah memberlakukan kerja dari rumah (WFH) atau mengurangi kapasitas jumlah pekerja di tempat kerja sampai 50\% atau $25 \%$. Jika diharuskan bekerja di tempat kerja diharapkan tetap melaksanakan protokol kesehatan. Sebelum memasuki kantor mencuci tangan dulu dengan sabun di air yang mengalir atau jika tidak memungkinkan dapat menggunakan hand sanitizer dan pengecekan 
suhu tubuh. Selama bekerja pun diharapkan menggunakan masker, menjaga jarak dengan teman kerja, tidak bersalaman atau bersentuhan, runtin membersihkan peralatan kerja, membawa tempat makan, minum, dan alat solat sendiri.

3. Selalu menjaga kebersihan lingkungan tempat kerja

Kebersihan lingkungan tempat kerja perlu diperhatikan dengan baik seperti membersihkan pegangan pintu dan tangga, tombol lift, peralatan kantor, dan fasilitas umum lainnya secara berkala setiap empat jam sekali dengan menggunakan desinsfektan. Selain itu perlu memperhatikan pula sirkulasi udara, mengatur sinar matahari yang masuk ruangan kerja, dan pembersihan filter AC.

4. Setelah bepergian wajib untuk mencegah penyebaran virus

Setelah bepergian tidak kontak langsung dengan orang rumah secara langsung, diharapkan membersihkan diri terlebih dahulu agar virus yang menempel di bagian tubuh dapat langsung mati, segera mencuci pakaian, menyemprot tas, ponsel, laptop dan pulpen menggunakan cairan disinfektan, menjemur sepatu dan sandal di bawah terik matahari.

5. Selalu menjaga daya tahan tubuh selama menjalani kenormalan baru

Menjaga daya tahan tubuh dapat dilakukan dengan istirahat yang cukup, minum air putih yang banyak, makan sayuran dan buah, rutin berolahraga, minum vitamin, berjemur di bawah sinar matahari di pagi hari, dan selalu mencuci tangan setelah beraktivitas.

6. Tidak sembarangan mengkonsumsi makanan dan obat-obatan

Konsumsilah makan yang sehat dan bergizi seperti empat sehat lima sempurna. Selektif dalam membeli makanan, minuman dan obat-obatan. Periksalah kehalalan, label, izin edar dan tanggal kadaluarsa sebelum membelinya, selalu melihat adanya rekmendasi dari Badan Pengawas Obat dan Makanan (BPOM).

7. Membeli obat dan makanan secara aman

Transaksi jual beli secara online sangat diminati di masa pandemi COVID-19 ini untuk mengurangi resiko penyebaran virus melalui transaksi jual beli secara langsung. Transaksi secara online perlu memperhatikan spesifikasi produk, komentar-komentar dari pembeli sebelumnya untuk mengurangi resiko penipuan.

8. Pencegahan penyebaran virus di tempat makan umum

Pihak penyedia wajib memperhatikan kebersihan tempat makan, alat masak, proses memasak, kesegaran makanan, serta pelayanan yang diberikan. Ketika transaksi antara pembeli dan penjual wajib sebelumnya untuk cuci tangan atau pakai hand sanitizer, menggunakan masker, menjaga jaga jaran, dan dianjurkan untuk tidak makan di tempat.

Masa kenormalan baru ini perlu dijalani secara sinergi dari semua kalangan baik pemerintah dan masyarakat. Pemerintah bijak dalam mengeluarkan berbagai kebijakan dan berpihak untuk kesejahteraan masyarakat. Begitu pula, masyarakat pun perlu waspada dan memiliki kontrol diri yang tinggi untuk mencegah penyebaran virus COVID-19. 


\section{Penyesuaian Diri dengan Kenormalan Baru}

Merebaknya penyebaran virus COVID-19 secara cepat sehingga WHO menetapkan sebagai pandemi telah memberikan dampak yang buruk terhadap tatanan kehidupan masyarakat. Berbagai dampak terasakan berat oleh masyarakat diantaranya kehilangan nyawa atau kematian, penurunan dan pelambatan ekonomi (resesi), terganggu aktivitas pendidikan, ekonomi dan sosial, dan yang paling mengkhawatirkan dampak psikologis dan perubahan perilaku masyarakat (Agung, 2020). Pandemi COVID-19 yang masih melanda tetapi kehidupan harus berjalan, roda ekonomi mesti digerakkan, di saat yang sama perlu kewaspadaan agar penyebaran virus dapat ditekan. Menghadapi tantangan-tantangan di masa kenormalan baru ini diperlukan adaptasi kebiasaan baru untuk menjalankan kehidupan sehari-hari.

Menghadapi tantangan kehidupan di masa kenormalan baru, sebagai warga negara yang baik, masyarakat wajib mentaati seluruh protokol yang telah ditetapkan pemerintah. Masyarakat perlu memiliki kontrol diri yang tinggi dalam menyesuaikan dengan keadaan baru di tengah wabah yang masih melanda. Menurut Schneider (Fanani \& Jainurakhma, 2020), penyesuaian diri adalah upaya individu untuk mengatasi atau memenuhi kebutuhan diri, ketegangan, frustasi, dan konflik untuk mendapatkan keharmonisan dan keselarasan antara tuntutan lingkungan tempat tinggal dengan tuntutan diri sendiri. Ginting (2019) menambahkan dalam proses penyesuian diri selalu terjadi hubungan antara tekanan dari dalam diri dengan suatu stimulus atau tuntutan lingkungan sosial yang ada.

Pada dasarnya penyesuaian diri memiliki dua aspek yaitu penyesuaian pribadi dan penyesuaian sosial (Choirudin, 2016). Penyesuaian pribadi adalah kemampuan individu untuk menyadari sepenuhnya siapa dirinya, menerima kelebihan dan kekurangan dirinya, dan mampu bertindak obyektif sesuai dengan kondisi dirinya sehingga tercapai hubungan yang harmonis antara dirinya dengan lingkugan sekitar. Sedangkan penyesuaian sosial adalah penyesuaian yang dilakukan individu dalam interaksi dengan masyarakat sehingga menimbulkan suatu pola tingkah laku yang sesuai dengan aturan, hukum, adat, nilai, dan norma yang harus dipatuhi bersama dalam rangka menyelesaikan berbagai persoalan kehidupan sehari-hari.

Kegagalan dalam penyesuaian diri secara positif dapat mengakibatkan individu bertingkah laku serba salah, tidak terarah, emosional, sikap yang tidak realistik dan agresif (Schneider, dalam Fanani \& Jainurakhma, 2020). Adapun faktor-faktor yang mempengaruhi hal tersebut diantaranya kondisi fisik (kesehatan dan hereditas), kepribadian (motivasi untuk berubah, regulasi diri dan intelegensi), proses belajar (belajar, pengalaman, latihan, determinasi diri), lingkungan (lingkungan keluarga, sekolah, masyarakat), agama dan budaya (Fanani \& Jainurakhma, 2020).

Menurut Shrivastava \& Schneider (Mahardhani, 2020) penyesuaian diri dapat ditinjau dari tiga pandang yaitu penyesuaian diri sebagai adaptasi (adaptation), penyesuaian diri sebagai bentuk konformitas (conformity), dan penyesuaian diri sebagai usaha penguasaan (mastery). 
1. Penyesuaian diri sebagai adaptasi, pada umumnya lebih mengarah kepada penyesuaian diri dalam hal fisik, fisiologi atau biologis (self maintenance atau survival). Dengan demikian, penyesuaian diri diartikan sebagai usaha mempertahankan diri secara fisik untuk bertahan hidup dalam kondisi pandemi.

2. Penyesuaian diri sebagai bentuk konformitas terhadap suatu norma. Menurut sudut pandang ini, individu mampu menghindarkan diri dalam penyimpangan perilaku, baik secara moral, sosial, atau emosional. Individu akan diarahkan dalam tuntutan konformitas dan dirinya akan terancam jika perilaku yang diperbuatnya tidak sesuai dengan norma yang berlaku.

3. Penyesuaian diri sebagai usaha penguasaan. Maksudnya, penyesuaian diri dalam kemampuan untuk merencanakan dan mengorganisir respon sehingga tidak akan ada konflik, frustasi atau kesulitan. Makna lainnya adalah penyesuaian diri dimaksudkan sebagai kemampuan individu dalam menguasi dan mengembangkan diri sehingga dorongan, emosi, dan kebiasaan menjadi lebih terkontrol dan terarah.

Dilihat dari berbagai sudut pandang di atas, jelaslah penyesuaian secara fisik, konformitas, dan penguasaan diri yang baik diperlukan untuk menghadapi tantangan kehidupan dalam kondisi kenormalan baru ini. Di masa pandemi ini menuntut penyesuaian diri untuk hidup bersih dan sehat dengan cara meningkatkan daya tahan tubuh dan menjalankan protokol kesehatan agar tidak terinfeksi virus COVID-19.

\section{Strategi Meningkatkan Kontrol Diri di Masa Pandemi COVID-19}

Secara umum kontrol diri diartikan sebagai tindakan menahan diri. Kontrol diri diperlukan untuk menghindari dari perbuatan-perbuatan yang merugikan dirinya untuk saat ini atau masa yang akan datang. Menurut Logue (Juntika Nurihsan, 2012, hlm. 69), self control as the choice of the large more delayed outcome. Makna kontrol diri menurut Logue lebih menekankan pada pilihan yang lebih bermanfaat daripada memilih untuk kepuasaan sesaat. Menurut Averill (Istiqlal, 2019) mengemukakan bahwa kontrol diri merupakan komponen psikologis yang sederhana mencakup kemampuan individu untuk memodifikasi perilaku, mengelola informasi yang tidak diinginkan dengan cara menginterpretasikan, dan memilih suatu tindakan berdasarkan suatu yang diyakininya. Secara luas, kontrol diri diartikan sebagai kemampuan untuk mengubah dan menyesuaikan diri sehingga tercermin perilaku yang lebih baik dan sesuai antara diri dengan lingkungannya (Tangney, dkk., 2004). Menambahkan pendapat sebelumnya, Calhoun \& Acocela (1990) mengartikan kontrol diri sebagai kecakapan individu untuk membaca situasi serta mengelola diri dan lingkungannya untuk keperluan adaptasi dan sosialisasi (Adani, 2018).

Terdapat tiga aspek kontrol diri menurut Averill (Istiqlal, 2019) yaitu mengontrol perilaku (behavior control), mengontrol kognisi (cognitive control), dan mengontrol keputusan (decisional control). Mengontrol perilaku merupakan kemampuan untuk memodifikasi perilaku yang dimanifestasikan dalam tindakan langsung terhadap lingkungan. Mengontrol kognisi merupakan kemampuan individu mengolah informasi 
yang diterima dengan cara menginterpretasikan, menilai, atau menggabungkan suatu kejadian dalam suatu kerangka kognitif sebagai adaptasi psikologi untuk mengurangi tekanan. Mengontrol keputusan merupakan sebuah kemampuan individu untuk memilah dan memilih hasil yang diyakini dalam menentukan keputusan terbaik. Tangney, dkk. (2004) menambahkan melanggar kebiasaan (breaking habits), menahan godaan, dan disiplin diri termasuk ke dalam aspek-aspek kontrol diri pula.

Adapun strategi kontrol diri menurut Juntika Nurihsan (2012, hlm. 71) sebagai berikut.

1. Ingat terus pada Tuhan Yang Maha Esa sebagai pengatur kehidupan.

2. Berpikir terlebih dahulu dengan menggunakan akal yang jernih keuntungan dan kerugian bagi diri sebelum melakukan sesuatu.

3. Mempertimbangkan keuntungan dan kerugian yang dapat ditimbulkan dari perbuatan yang dilakukan.

4. Bersabar apabila terkena musibah.

5. Bersabar dalam mengerjakan sesuatu yang diperintahkan Tuhan.

6. Bersabar dalam menghindari sesuatu yang dilarang Tuhan.

7. Mensyukuri nikmat.

8. Berempati kepada orang lain.

Adapun beberapa rekomendasi dari WHO (2020), APA (2020), dan hasil penelitian ahli psikologi untuk mengurasi, dan mengatasi dampak psikologis COVID-19 (Agung, 2020), sebagai berikut.

1. Tidak berlebihan mengakses informasi, utamakan sumber informasi terpercaya, jangan terlalu terlibat secara emosional dengan pemberitaan yang dapat mengarahkan pada emosi negatif.

2. Menjaga koneksitas dengan orang lain. Selama melakukan social distancing, perlu tetap menjaga koneksitas dengan orang lain, untuk membangun solidaritas, saling mendukung, dan membangun relasi positif untuk meningkatkan kebahagiaan.

3. Menjalankan aktivitas secara rutin tiap hari dengan melakukan kegiatan inoasi dan kreatif agar tetap semangan dan produktif.

4. Menggunakan strategi koping psikologis dalam mengatasi stres dengan membangun optimisme dan harapan positif bahwa situasi akan dapat dilalui dengan baik. Selain itu meningkatkan daya tahan tubuh dan psikis dengan pendekatan psiko-religius.

5. Tetap peduli pada situasi dan perubahan yang terjadi.

6. Terlibat aktif pada kegiatan prososial dengan berbagi, melakukan tindakan yang menimbulkan kebahagiaan pada orang lain.

7. Bersikap kooperatif dengan pro aktif melaporkan masalah-masalah sosial yang disebabkan dampak COVID-19 kepada pihak yang berwenang, sehingga membantu terciptanya suasana kondusif dan harmonis di lingkungan masyarakat. 
Berdasarkan pemaparan di atas, kontrol diri merupakan kemampuan untuk mengelola pikir, rasa, dan raga dalam rangka pengendalian dan penyesuaian diri dengan situasi atau lingkungan yang baru. Individu atau masyarakat dengan kontrol diri yang baik pada masa pandemi COVID-19 ini dapat lebih mudah bersosialisasi dengan kemampuannya mengelola pikir, rasa, dan raga untuk beradaptasi dengan situasi dan kondisi sesuai lingkungannya. Pentingnya kontrol diri yang tinggi pada setiap individu atau masyarakat di masa pandemi COVID-19, perlu disertai pula dengan strategi-straegi untuk mematuhi protokol kesehatan yang ketat. Kontrol diri yang baik di kalangan masyarakat dapat menghindarkan dan menekan penularan virus COVID-19. Sebaliknya, menurut Gottfredson \& Hirschi (dalam Adani, 2018 ) jika kontrol diri masyarakat yang rendah cenderung mementingkan diri sendiri, acuh, atau tidak menyadari penderitaan dan kebutuhan orang lain dengan abai terhadap protokol kesehatan maka dipastikan kasus terinfeksi COVID-19 akan meroket.

\section{SIMPULAN}

Penyebaran pandemi COVID-19 secara cepat dan luas mengakibatkan perubahan signifikan pada seluruh aspek kehidupan masyarakat. Berbagai upaya seperti Pembatasan Sosial Berskala Besar (PSBB), berbagai kebijakan perekonomian, dan vaksinasi telah dilakukan pemerintah sebagai upaya memutus mata rantai penyebaran dan mitigasi dampak COVID-19. Oleh karena itu, menghadapi pandemi dalam kenormalan baru, masyarakat sebagai bagian dari warga negara yang bijaksana dituntut untuk menjadi individu yang berkarakter disiplin yang mampu beradaptasi dan mengontrol diri. Melalui strategi-strategi kontrol diri dalam hidup bersih dan sehat serta menjalankan protokol kesehatan dalam bingkai solidaritas, kebersamaan dan kesatuan dari semua pihak menjadi kunci utama dalam menghadapi dan meredam pademi COVID-19 agar segera berakhir.

\section{DAFTAR PUSTAKA}

Adani, Neno. (2018). Pengaruh Keterlibatan Ayah Terhadap Kontrol Diri pada Remaja Akhir di Jakarta. (Skripsi). Program Studi Psikologi, Uniersitas Negeri Jakarta. Jakarta.

Adrian, Kevin. (2021). Informasi Berbagai Vaksin COVID-19 di Indonesia. [Online]. Diakses dari https://www.alodokter.com/informasi-berbagai-vaksin-covid-19-diindonesia (Diakses pada 21 Mei 2021).

Agung, I. M. (2020). Memahami Pandemi Covid-19 Dalam Perspektif Psikologi Sosial. Psikobuletin: Buletin Ilmiah Psikologi, 1(2), hlm. 68-84.

Biro Humas Kemnaker. (2020). Menaker: Badai Pasti Berlalu, Panggil Kembali Pekerja yang ter-PHK Nanti. [Online]. Diakses dari https://www.kemnaker.go.id/news/detail/menaker-badai-pasti-berlalu-panggilkembali-pekerja-yang-ter-phk-nanti (Diakses pada 18 November 2020). 
70 | Kurnia - Strategi Meningkatkan Kontrol ...

Choirudin, M. (2016). Penyesuaian Diri: Sebagai Upaya Mencapai Kesejahteraan Jiwa. Hisbah: Jurnal Bimbingan Konseling Dan Dakwah Islam. https://doi.org/10.14421/hisbah.2015.121-07

Fanani, Q., \& Jainurakhma, J. (2020). Kemampuan penyesuaian diri mahasiswa terhadap pembelajaran daring di tengah pandemi Covid-19. Jurnal KomtekInfo, 7(4), hlm, 285-292.

Ginting, P. (2019). Penyesuaian Diri Dalam Organisasi. Mpu Procuratio: Jurnal Penelitian Manajemen, 1(2), 2019. file:///C:/Users/User/Downloads/314-Article Text-553-1-10-20191102.pdf

Hurlock, Elizabeth B. (2011). Psikologi Perkembangan: Suatu Pendekatan Sepanjang Rentang Kehidupan. Jakarta: Erlangga.

Iskandarsyah, A \& Yudiana, W (2020). Informasi COVID-19, Perilaku Sehat Dan Kondisi Psikologis Di Indonesia. Laporan Survei. Fakultas Psikologi Universitas Padjajaran.

Istiqlal, Arfin Hatta. (2019). Hubungan Kontrol Diri dengan Impulse Buying pada Mahasiswa. (Skripsi). Program Studi Psikologi, Universitas Islam Negeri Sunan Ampel, Surabaya.

Juntika Nurihsan, Ahmad. (2012). Stategi Layanan Bimbingan dan Konseling. Bandung: PT. Refika Aditama.

Kelly, H. (2011). The Classical Definition of a Pandemic is Not Elusive. Bulletin of the World Health Organization, 89(1), hlm. 540-541. doi: 10.2471/BLT.11.088815 dari http://www9.who.int/bulletin/volumes/89/7/11-088815/en/

Lazarus, R. S. (1976). Patern of Adjustment. Third Edition. Tokyo: McGraw Hill Kogakusha, Ltd.

Li, S., Wang, Y., Xue, J., Zhao, N. \& Zhu, T. I. (2020). The Impact of COVID-19 Epidemic Declaration on Psychological Consequences: A Study on Active Weibo Users International Journal of Environment Research and Public Health, 17, 2032.

Mahardhani, A. J., \& KP, M. (2020). Menjadi Warga Negara yang Baik pada Masa Pandemi Covid-19: Persprektif Kenormalan Baru. JPK (Jurnal Pancasila dan Kewarganegaraan), 5(2), hlm. 65-76.

Rohmah, N. (2021). ADAPTASI KEBIASAAN BARU DI MASA PANDEMI COVID19. AL-MIKRAJ: Jurnal Studi Islam dan Humaniora (E-ISSN: 2745-4584), 1(2), hlm. 78-90.

Sugiyono. (2018). Metode Penelitian Kualitatif (3rd ed.). Bandung: Alfabeta.

Tangney, J. P., Baumister, R. F., \& Boone, A.L. (2004). High Self-Control Predict Good Adjustment, Less, Pathology, Better Grades, and Interpersonal Success. Journal Of Personality, 72(2), hlm. 271-282. 